\title{
RISK EFFECT ON CONTRIBUTION OF PARTICIPANTS IN SHARIA INSURANCE INDONESIA
}

\author{
Anisa Istiqomah ${ }^{\mathrm{a}}$ \\ Vidia Gati ${ }^{b}$ \\ a,b Islamic Economics, Faculty of Economics and Business, Islamic State University of Sunan Ampel \\ Email: aanisaistiqomah@gmail.com ${ }^{\text {a }}$ vidiagati@uinsby.ac.id ${ }^{b}$
}

\begin{abstract}
ARTICLE HISTORY
ABSTRACT

Received:

13 March 2020

Revised:

4 June 2020

Accepted:

05 June 2020

Online available:

30 June 2020

Keywords:

Contribution,

Islamic insurance,

Participant,

Risk-based,

Tabarru' funds

*Correspondence:

Name: Anisa Istiqomah

E-mail:

aanisaistiqomah@gmail.com

This study aims to prove the effect of operational costs, investment returns, claims and minimum risk-based tabarru' funds partially and simultaneously on the contribution of Islamic general insurance in Indonesia 2015-2018. This study uses a quantitative approach with secondary data in the form of publication of annual Islamic financial statements and sample selection using a purposive sampling technique. The amount of data is 11 companies with observations over four years to obtain 44 observational data used as samples in this study. The technique used is regression analysis using a fixed effect model (FEM) panel data. The results illustrate that partially, minimum variable costs based on operational risk, claims, and tabarru' funds have a significant positive effect on participant contributions. Thus proving that the higher the minimum operational costs based on claims, and tabarru' 'will influence the determination of participant contributions. As for investment returns, it has no effect on determining participant contributions because funds can be allocated to increase assets. Simultaneous statistical test results from operational costs, investment returns, claims, minimum risk-based funds are influenced by participant contributions. This research suggestion should be that Islamic general insurance companies can conduct regular audits on the use of operational costs to make it more efficient so that the allocation of contribution costs can be directed towards the growth of assets or minimum risk-based tabarru' funds of the company.
\end{abstract}

\section{INTRODUCTION}

The need for sharia-based financial institutions requires guarantees in muamalah practices in accordance with kaffah sharia principles to achieve prosperity and tranquility in his life because basically the Muslim community views conventional insurance operations doubtfully, they even believe that the practice has flaws from the perspective of the sharia. Non-bank financial institutions that play a role as one of the pillars of the national economy are the insurance industry (Hwang \& Greenford, 2005). 
Insurance is one of the most important instruments in the financial market in managing uncertainty risk (Duzuki, 2015). The practice of Islamic insurance is the answer to the needs of Muslims in anticipating the possibility of risk in Islamic way (Al Arif \& Muhammad Nur R., 2012).

According to the World Takaful Report, the global sharia insurance market is concentrated in GCC member countries and Southeast Asia (Middle East Global Advisors, 2016). Gross contribution of sharia insurance in Southeast Asian countries ranks second largest after the country of Saudi Arabia (Kurnia, 2017). Based on data released by Ernst \& Young Global Limited (2014) the amount of gross sharia insurance contribution in Southeast Asia was dominated by Malaysia at $71.28 \%$, Indonesia at $22.72 \%$, and the rest were other countries. This fact looks reasonable because the two countries constitute the majority of the Muslim population and Malaysia is one of the countries that is aggressively developing Islamic insurance. In addition, the prospect of the sharia insurance industry is predicted to continue to develop in the future. Based on the 2014 Global Takaful Insight report, the global sharia insurance industry experiences growth of $14 \%$ annually and the insurance sector acts as a financial intermediary institution that has been integrated into the broader financial industry (Ernst \& Young Global Limited, 2014).

The amount of insurance premiums received by insurance companies tends to increase every year (Kurnia, 2017). Determination of participant contribution rates plays an important role for the survival of the company where it is expected that bidding on the same participant contribution rates can cover high losses or vice versa by closing the same losses but participant contribution rates are low (Indriani et al., 2019). An increase or decrease in participant contributions is determined by the company by considering its components. Projections that determine the contribution of participants are a risk, savings, and investment (Archer et al., 2009). Soedibjo and Fitriati (2009) reinforce the statement by stating that the achievement of a participant contribution portfolio that can break even optimally is very dependent on the type of product being marketed, operational costs, investment returns, and the level of risk of potential participants. In addition, the benchmark for determining the number of participant contributions also depends on the level of risk and the amount of coverage. If the risk of loss that may occur to participants is very high, the guarantor or the company will calculate in detail the level of payment of participant contributions that are much higher (Triandaru \& Budisantoro, 2006).

In Islamic insurance, the risk is manifested in the form of claims to be received by the insured so that the insurance company can project and calculate the amount of the cost of compensation incurred. A possibility of unexpected results will occur that can cause loss. Claim payment is one of the insurance company risks that must be managed properly. Insurance companies as managers must complete the claim 
process quickly, precisely, and efficiently in accordance with the mandate they receive (Nasution, 2008).

In general, the number of participant contributions or premiums will be the main consideration for the insured where the participant contributions can cover the risks that occur in insurance companies (Djojosoedarsono, 2003). The claim ratio is calculated by the amount of claim expense to premium (Kurnia, 2017). The increasing claim value and claim submission will affect the contribution of company participants, so the company will plan a strategy to reduce the contribution rate of participants to be a little more expensive because the position of claims on insurance companies is an expense or cost that must be borne by the company (Sianturi, 2014). Then the benchmark for determining participant contribution rates follows the components covering all forms of risks that occur in the company seen in the minimum risk-based tabarru' funds component in the company's financial statements where the components contain all credit risk, liquidity risk, market risk, insurance risk, and operational risk.

The survival of sharia insurance companies cannot be separated from the operational processes (operating expenses) which are all forms of costs incurred by insurance companies to be able to support the company's operational activities to create profits, in accordance with the decision of the Minister of Finance No. 424 in 2003. Large operational activities require more costs, so the company will increase the cost of participant contributions to meet the cost needs.

Sharia insurance companies, in addition to collecting participant contribution funds as a source of income, also make investments that are used as a future capital. The investment profit-sharing in the form of profit or return will be distributed to participants and insurance companies in accordance with the initial agreement of both parties. Investment is one component that drives the progress of Islamic insurance institutions.

Insurance companies need to determine the appropriate amount of participant contributions so that the company can achieve the desired expected return and high investment returns for the coming year (Nasution, 2008). The amount of profit-sharing from investment returns depends on the condition of the company: the greater the profit gained, the greater the profit-sharing provided for participants (Sula, 2004). This is in line with research by Astria (2009). If the acquisition of investment returns is high, the company will have the desired profit or expected return to finance operational activities, as well as the components that are borne by the insurance company (Astria, 2009). This will also have an impact on determining the low contribution of participants (Sula, 2004). The acquisition of higher investment results shows the good performance and ability of the company in managing participant funds. This capability will have a good impact on increasing a participant's credibility and trust in the insurance company. 
Some empirical studies that examine the determination of participant contributions include research by Wardhani and Septiarini (2017) which measures operational costs, investment returns, and claims for participant contributions using sharia life insurance in Indonesia in 2013-2015 as research objects. The results showed that the dependent variable, namely operational costs, investment returns, and claims, had a significant and positive effect on participant contributions. Inversely proportional to current research. Using Islamic general insurance in Indonesia as an object of research, this study shows that the investment return variable is not significant. That is because the economic cycle conditions in 2015-2018 experienced a trade war between China and the United States so that the impact on the Indonesian economy, causing investment returns did not experience good growth even minus. The allocation of funds for investment is likely to be transferred to company assets.

Based on the research description of Archer et al. (2009) and strengthened by Soedibjo \& Fitriati's research (2009), projections that determine participant's contributions are a risk, savings, investment, and achievement of participant contribution portfolios and can optimally break even depending on the types of products marketed, operating costs, investment's results, and the level of risk of potential participants. Based on the statement, in this research, there are risk factors contained in the risk-based minimum tabarru' variable, one of the components contained in the company's financial statements that contain all credit risk, liquidity risk, market risk, insurance risk, and operational risk.

Overall, this research aims to find empirical evidence regarding the factors that influence the determination of the contribution of sharia general insurance participants in Indonesia by looking at the effect of the variable operational costs, investment returns, claims, and risk-based minimum tabarru' funds on participant contributions.

\section{LITERATUR REVIEW}

Wahbah Az-Zuhaili as a contemporary fiqh expert in insurance divides sharia insurance into two forms namely at-ta'min bi qist sabitand at-ta'min at-ta'awun. Helpinsurance (ta'awun) which means the agreement of both parties who pay a sum of money to protect in the event of a disaster or misfortune and other parties supporting the payment of compensation from the disaster that befell the person (Prodjodikoro, 1958). Billah (2001) defines coverage as having the meaning of sharing responsibilities, joint guarantees, responsibilities, guarantees or guarantees. In a resolution, Billah (2001) interprets takaful with a mutual guarantee given by a group of people living in the same community against certain risks or disasters that afflict life, property, or any other forms of valuable objects. 
Table 1

Difference between Conventional Insurance and Sharia Insurance

\begin{tabular}{|c|c|c|c|}
\hline No & Principle & Conventional Insurance & Sharia Insurance \\
\hline 1 & Concept & $\begin{array}{l}\text { Agreement between two or more } \\
\text { parties by which the guarantor } \\
\text { binds himself to the insured, by } \\
\text { receiving insurance premiums, to } \\
\text { provide a replacement to the } \\
\text { insurer. }\end{array}$ & $\begin{array}{l}\text { A group of people who help each other, } \\
\text { guarantee each other, and cooperate with each } \\
\text { other, the participants are willing to spend funds } \\
\text { intended for social funds (tabarru') }\end{array}$ \\
\hline 2 & $\begin{array}{l}\text { Contract } \\
\text { "Akad" }\end{array}$ & $\begin{array}{l}\text { Sale and purchase contract } \\
\text { (mu'awadhah akad, idz'aan akad, } \\
\text { ghara akad, and mulzim akad) and } \\
\text { tabadduli akad. }\end{array}$ & $\begin{array}{l}\text { Tabarru contract, tijarah contract (mudharabah, } \\
\text { wakalah, wadiah, syirkah, etc.). }\end{array}$ \\
\hline 3 & $\begin{array}{l}\text { Collateral and } \\
\text { Risk }\end{array}$ & $\begin{array}{l}\text { Transfer of risk, namely the transfer } \\
\text { of risk from the insured to the } \\
\text { insurer. }\end{array}$ & $\begin{array}{l}\text { participants endure one another or help one } \\
\text { another (ta'awun) }\end{array}$ \\
\hline 4 & Investment & $\begin{array}{l}\text { Free to invest within the limits of } \\
\text { statutory provisions and is not } \\
\text { limited to halal and haram an object } \\
\text { or system that is invested. }\end{array}$ & $\begin{array}{l}\text { Placing investments under applicable laws and } \\
\text { regulations and guaranteed things that are } \\
\text { prohibited by Islamic law such as free from usury } \\
\text { and places of investment that are lawful. }\end{array}$ \\
\hline 5 & $\begin{array}{l}\text { Elements of } \\
\text { Participant } \\
\text { Contribution }\end{array}$ & $\begin{array}{l}\text { The premium element consists of } \\
\text { mortality tables, interest, cost of } \\
\text { insurance. }\end{array}$ & $\begin{array}{l}\text { Dues or contributions consist of tabarru' } \\
\text { elements and savings (which do not contain } \\
\text { usury). Tabarru' is also calculated from the } \\
\text { mortality table but without usury or interest } \\
\text { calculation. }\end{array}$ \\
\hline 6 & $\begin{array}{l}\text { Claim } \\
\text { Payment } \\
\text { Source }\end{array}$ & $\begin{array}{l}\text { The source of claim costs is from } \\
\text { company accounts, as a } \\
\text { consequence of the guarantor } \\
\text { against the insured. Pure business, } \\
\text { without any spiritual nuance. }\end{array}$ & $\begin{array}{l}\text { The claim payment source is obtained from the } \\
\text { tabarru' account, which is the participant bears } \\
\text { mutual responsibility. If a participant gets a } \\
\text { misfortune, another participant shares the risk. }\end{array}$ \\
\hline 7 & Profit & $\begin{array}{l}\text { The profits from surplus } \\
\text { underwriting, reinsurance } \\
\text { commission, and investment } \\
\text { returns are all the profits of the } \\
\text { company. }\end{array}$ & $\begin{array}{l}\text { Profits derived from underwriting surpluses, } \\
\text { reinsurance commissions, and investment } \\
\text { returns are not wholly owned by the company but } \\
\text { are made for profit sharing (mudhrabah) with } \\
\text { participants }\end{array}$ \\
\hline
\end{tabular}

Source: Wirdyaningsih (2005)

The mechanism for managing participant contribution funds (premiums) is divided into two systems (Sula, 2004), namely:

1. System on saving products (saving)

Each participant must deposit funds (some money) to the insurance company. The amount of the cost of a participant's contribution depends on the participant's finances and the company's determination of the minimum premium to be paid. Each participant contribution fee (premium) paid to the insurance company will be separated in different accounts and immediately included in two accounts, namely Tabarru' special account and savings account (Anwar, 2004). 


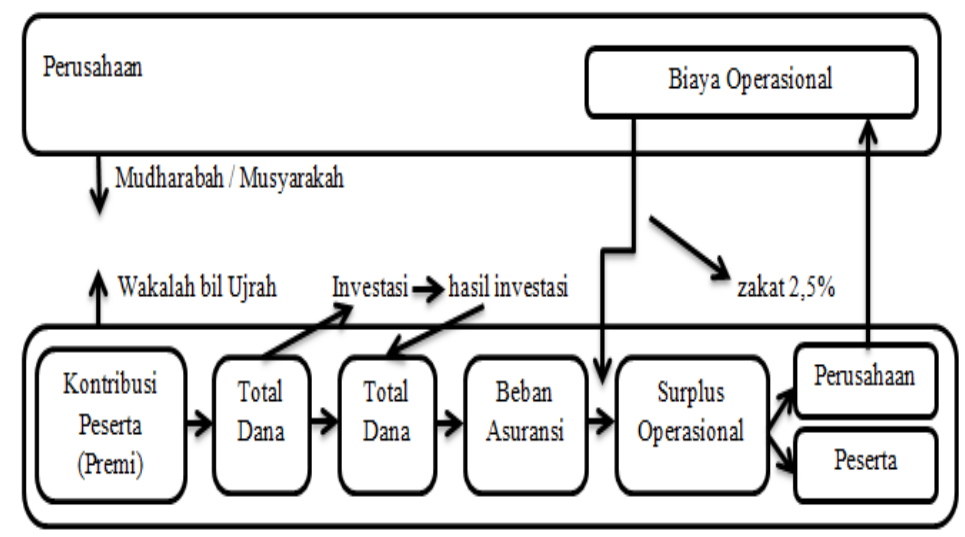

Figure 1. Mechanisms that contain Savings Elements Source: Soemitra (2009)

\section{Premium system with no savings element}

The participants contributions (premiums) that have been paid by insurance participants will be put on the tabarru' fund account as a form of funds specifically intended for benevolence, help, guarantee, mutual guarantee, and bear if there are several conditions. First, when another participant is struck by a disaster and the participant dies, the second is when the participant's agreement will end (if there is a company surplus fund).

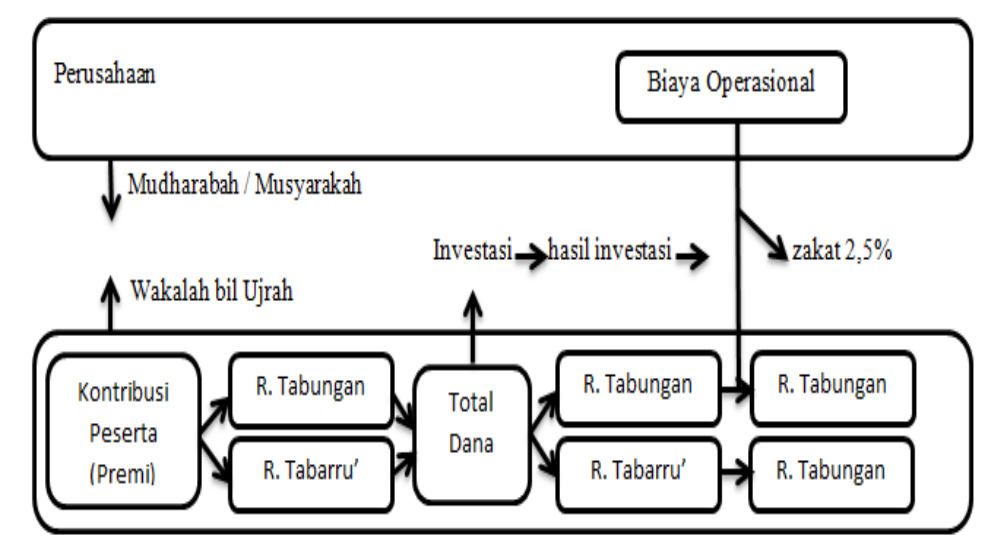

Figure 2. Mechanisms that do not contain savings Source: Soemitra (2009)

Participant contribution is the nominal price paid by the participants of the policyholder so that the size of the contribution depends on the agreement or agreement (policy) that has been made in accordance with the provisions of the insurance company (Huda \& Nasution, 2009).

Islamic insurance companies consider various components in determining the contribution of participants in accordance with the policies of each company. Puspitasari (2015) explains that the ideal participant contribution is the rate that must cover claims as well as various insurance costs and company profits. In line with the components that influence the contribution of participants are a risk, savings, and 
investment (Archer et al., 2009). Strengthened in Soedibjo \& Fitriati's (2009) research which states that achieving an optimal contribution from participant portfolio can break even, depending on the type of product being marketed, operational costs, investment returns, and the level of risk of potential participants.

Determination of the contribution rate of participants plays an important role for the survival of the company and participants. Bidding on the same participant contribution rates is expected to cover high losses or vice versa, namely by closing the same losses but participant contribution rates are low (Indriani et al., 2019). So that several factors determine the nominal contribution rate of participants including operational costs.

One of the factors determining the contribution of participants is operating costs (operating expenses). These costs are closely related to all forms of operational activities carried out by the company so that these costs support the company's daily performance (Purnomo, 2017). Operating expenses become the burden of the company which bears all operational activities of the company, whether marketing expenses, administrative expenses, commission expenses, or development expenses (Dewi \& Witjaksono, 2015). Wardhani \& Septiarini (2017) also explained that the source of operational costs for insurance companies was obtained from the cost of participant contributions. If the company cannot improve its operational costs, the company will increase the cost of participant contributions (Wardhani \& Septiarini, 2017). The smaller the company's operational costs, the better the company's performance in competing (Purnomo, 2017). This is because the company can manage operational costs effectively and efficiently so that the allocation of funds that were originally allocated to operational costs will be more productive if allocated in the investment sector and produce multiple profits for the company.

Supported by the results of previous studies conducted by Soedibjo and Fitriati (2009) who explained that the higher the cost of participant contributions, the amount of fund allocation for insurance company operational costs will also be even greater. Larger operational activities will require more operational costs so the company will increase the cost of participant contributions to meet those operational costs.

In addition to operational costs, investment returns can determine participant contributions. Investment returns are income derived from investment in selected investment instruments so that within the estimated time will get a profit or loss depending on the value of the investment in a certain period. Achievement of targets from specified investment returns can be done by insurance companies by measuring the number of contributions that will be given to participants (Nasution, 2008). The amount of profit-sharing from investment returns depends on company conditions. The greater the profit obtained by the company, the profit-sharing given to participants is greater (Sula, 2004).

This statement is in line with Astria's research (2009). If the acquisition of investment returns is high, the company already has the desired profit or expected 
return so that in financing operational activities, the components that are borne by the insurance company can be overcome. This will have an impact on determining the contribution of participants who could be low (Astria, 2009). The acquisition of higher investment results shows the company's performance and ability to manage participant funds are getting better. This has a good impact on increasing a participant's credibility and trust in the insurance company.

Claim in DSN MUI Fatwa No. 21/DSN-MUI/X/2001 is a participant's right that must be granted by the insurance company according to the contract agreement and the claim can differ in the amount according to the participant's contribution given. Insurance claims are the rights of insurance participants and on the other hand, it becomes an obligation for insurance companies to be bound in the contract. One of the principles of the sharia insurance business is the sharing of risk between participants and companies in protecting participants (Saniatuslima \& Suprayogi, 2015). When there is an increase in claims made by participants, the company will increase the cost of participant contributions. This is because the company has an obligation to pay obligations to participants, and to fulfill these obligations, the greater the role of participant contributions (ta'awun) will increasingly be able to support the company.

Participant contribution rates can be said to be ideal when they are able to cover claims and various insurance costs and company profits (Puspitasari, 2015). Increasing the submission of claims will affect the effectiveness and efficiency of company profits, the company's strategy will reduce the contribution rate of participants to be a little more expensive. Determination of the nominal amount of the claim is the most important thing in forming the amount of the premium.

Determination of participant contribution rates also depends on the high or low-risk opportunities that participants have and the amount of coverage. If the risk possessed by the participant is very high, the insurance company will project and calculate in detail the likely risks that will occur to increase the loss and contribution charged to the participant (Triandaru \& Budisantoro, 2006). Components that encompass all forms of risk that occur in the company are seen in the minimum riskbased tabarru' funds component in the company's financial statements where the component contains all credit risk, liquidity risk, market risk, insurance risk, and operational risk.

\section{Hypothesis}

Based on the description above, the hypothesis in this study is:

Hypothesis 1 : X1 affect $Y$;

Hypothesis 2 : $X 2$ affect $Y$;

Hypothesis $3: X 3$ affect $Y$;

Hypothesis $4: X 4$ affect $Y$;

Hypothesis $5: \mathrm{X} 1, \mathrm{X} 2, \mathrm{X} 3, \mathrm{X} 4$ affect $\mathrm{Y}$.

Published by University of Airlangga.

This is an open access article under the CC BY license (https://creativecommons.org/licenses/by-nc-sa/4.0/) 


\section{Conceptual Framework}

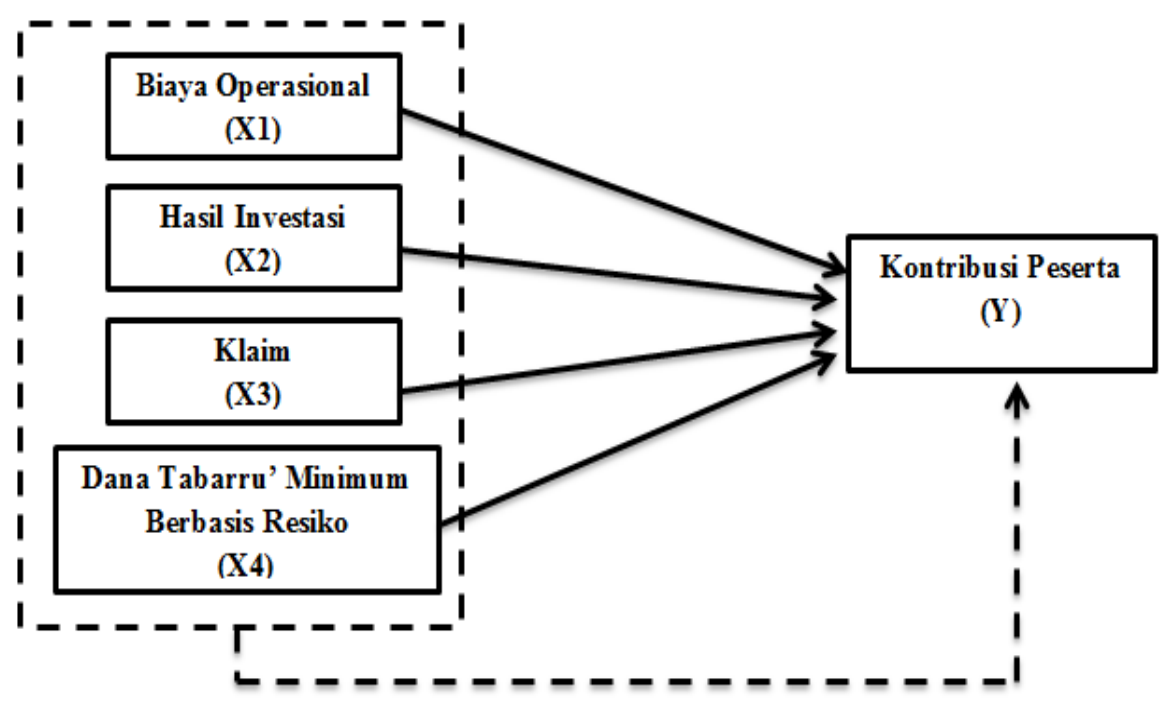

Keterangan :

$=$ Pengaruh secara parsial (individu)

$=$ Pengaruh secara simultan (bersama-sama)

Figure 3. Partial and Simultaneous Testing

Source: Concepted by author

So the regression equation is:

$$
Y=a+b 1 X 1+b 2 X 2+b 3 X 3+b 4 X 4
$$

\section{RESEARCH METHODS}

\section{Research Approach}

This study uses a quantitative approach that aims to make an estimate of the average and value of dependent variables based on independent variables and test the hypothesis of dependency characteristics by referring to Islamic insurance financial statement data. Data is collected from statistical publications published by the Financial Services Authority (OJK) from 2015 to 2018. This publication report contains various information such as gross premium growth, growth in the number of claims paid, the growth in the amount of wealth and investment, the balance of payments, growth in the claims ratio, minimum risk-based funds, and so on.

\section{Variable Identification}

1. Independent Variable

The independent variable is operational costs, investment returns, claims, and minimum risk-based tabarru' funds.

2. Dependent Variable

The dependent variable is the participant contribution variable. 


\section{Definition of Variable Operations}

Table 2

Definition of Variable Operations

\begin{tabular}{|c|c|c|}
\hline $\begin{array}{l}\text { Variable } \\
\text { Name }\end{array}$ & Explanatory & Indicator \\
\hline $\mathbf{Y}$ & Participant Contribution & Total gross participant contributions \\
\hline $\mathbf{x 1}$ & Operational Cost & $\begin{array}{l}\text { Total expenses or costs incurred by the } \\
\text { company }\end{array}$ \\
\hline $\mathbf{X} 2$ & Investment Returns & $\begin{array}{l}\text { Tabarru' funds investment income + company } \\
\text { investment income }\end{array}$ \\
\hline $\mathbf{X 3}$ & Claim & Total net claim insurance expenses \\
\hline X4 & $\begin{array}{l}\text { Risk-Based Minimum } \\
\text { Economic Funds (DTMBR) }\end{array}$ & $\begin{array}{l}\text { Minimum Risk Based Tabarru' Fund Amount } \\
\text { (DTMBR) }\end{array}$ \\
\hline
\end{tabular}

Source: Processed from Various Sources

\section{Data and Data Sources}

This study uses secondary data that has been collected by other parties and published openly to the public (Kuncoro, 2013). Secondary data in the form of financial statements of insurance companies that have Islamic financial statements in the form of a statement of financial position and a comprehensive income statement on company funds in 2015-2018. Secondary data sources in this study come from the official website of the Indonesian Sharia Insurance Association (AASI) and are registered with the OJK. In addition, data sourced from literature studies such as books and journals can be used to support other secondary data.

\section{Data Analysis Technique}

This research has fulfilled the classic assumption test. Data analysis techniques in this study used panel data regression analysis. Panel data (pooled data) is a combination of time series data and cross-section data. After that, hypothesis testing will be performed with a panel data regression model.

\section{Hypothesis Testing}

\section{Simultaneous Significance Test (F test)}

The $\mathrm{F}$ test can show whether all independent variables entered in the model have a joint influence on the dependent variable (Kuncoro, 2007). The significance of the calculated $F$ value less than 0.05 will reject $H_{0}$, so it is known that there is a relationship between the $X$ variable and the $Y$ variable. If the significance value of the calculated $F$ is greater than $0.05, H_{0}$ is accepted. This means that the variables $X$ and $Y$ have no relationship.

\section{Partial Significance Test (t-test)}

Partially, t-test examines the regression coefficient. This test can see whether there is a significant influence of an independent variable on the dependent variable if 
the other independent variables are considered constant (Ghozali, 2018). If the significance of $t$ arithmetic is less than 0.05 , there is an influence between variable $X$ on variable $\mathrm{Y}\left(\mathrm{H}_{0}\right.$ is accepted). Conversely, if the significance value of $\mathrm{t}$ arithmetic is more than 0.05 , there is no influence between the variable $X$ on the $Y$ variable.

\section{Research Result}

\section{Object of Research}

Samples of sharia insurance company research samples were taken as many as 11 companies during 2015-2018 to obtain 44 observational data. Sharia general insurance companies that are the object of research include:

Table 3

List of Sharia General Insurance Companies in Indonesia

\begin{tabular}{cl}
\hline No & \\
\hline $\mathbf{1}$ & PT Asuransi Adira Dinamika \\
$\mathbf{2}$ & PT Asuransi Allianz Utama Indonesia \\
$\mathbf{3}$ & PT Asuransi Bringin Sejahtera Artamakmur \\
$\mathbf{4}$ & PT Asuransi Jasa Raharja Putera \\
$\mathbf{5}$ & PT Asuransi Sinar Mas \\
$\mathbf{6}$ & PT Asuransi Staco Mandiri \\
$\mathbf{7}$ & PT Asuransi Tri Pakarta \\
$\mathbf{8}$ & PT Asuransi Umum Bumiputera Muda 1967 \\
$\mathbf{9}$ & PT Asuransi Umum Mega \\
$\mathbf{1 0}$ & PT Tugu Pratama Indonesia \\
$\mathbf{1 1}$ & PT Asuransi Wahana Tata \\
\hline
\end{tabular}

Source: OJK (2018)

This study has fulfilled the classical assumption test so that the next step is the selection of an appropriate estimation model

\section{Selecting Panel Data Estimation Model Data}

Table 4

Chow Test Result

\begin{tabular}{llcc}
\hline $\begin{array}{l}\text { Redundant Fixed Effects Test } \\
\text { Equation: FEM }\end{array}$ & & \\
Test Cross-section Fixed Effects & & & \\
\hline Effects Test & Statistic & d.f & Prob. \\
Cross-Section F & $\mathbf{7 . 8 2 8 1 3 6}$ & $(\mathbf{1 0 , 2 9 )}$ & $\mathbf{0 . 0 0 0 0}$
\end{tabular}

Source: Output Eviews

Based on the results of Table 4, it is known that the value of $p$-value is 0.0000 or smaller than the critical value used in this study, which is 0.05 or $5 \%$. Based on these results, the $\mathrm{H}_{0}$ hypothesis rejects the PLS model as an appropriate model and accepts the $\mathrm{H}_{1}$ hypothesis which states it uses the FEM model. Next, the test continues with the Hausman test which aims to determine the best model between the Fixed Effect Model (FEM). 
Table 5

Hausman Test Result

Correction Random Effects-Hausman Test

Equation: FEM

Test Cross-section Fixed Effects

\begin{tabular}{cccc}
\hline Test Summary & Chi-Sq. Statistic & Chi-Sq.d.f & Prob. \\
Cross-section random & $\mathbf{3 3 . 4 4 3 3 4 1}$ & $\mathbf{4}$ & $\mathbf{0 . 0 0 0 0}$ \\
\hline
\end{tabular}

Based on the results shown in Table 5, it is known that the value of Chi-Square is 33.443341 and the $p$-value is 0.0000 with a critical value of 5 percent. Based on the Hausman test results, by comparing the value of the $p$-value with the critical value, it appears that the value of the $p$-value of 0.0000 is smaller than the critical value used, which is 0.05 or $5 \%$. Therefore, the hypothesis $\mathrm{H}_{0}$ is rejected and accepts the $\mathrm{H}_{1}$ hypothesis which states that this study uses the Fixed Effect Model (FEM).

Based on the Fixed Effect Model (FEM) estimation results shown in Table 6, it can be seen that the operational cost variable slope (X1) is 0.343270 , the investment outcome variable slope $(X 2)$ is 0.135123 , and the claim variable slope $(X 3)$ is 0,244893 and risk-based minimum (X4) tabarru' funds' slope of 0.339324 . While the $p$-value for the operational cost variable $(X 1)$ is 0.0062 , the $p$-value of the investment return variable (X2) and claim (X3) is respectively 0.1300 and 0.0004 , and the p-value of minimum risk-based tabarru' funds $(X 4)$ is 0,0004 . If the independent variable is 0 , then $\mathrm{Y}$ is 0.618283 and the error term is 2.228608 . $\mathrm{R}$-squared value of 0.991704 or $99.17 \%$ and F-statistic of 247.6329 with Prob (F-statistics) of 0.000000.

Table 6

Fixed Effect Model (FEM) Estimated Results

\begin{tabular}{|c|c|c|c|c|}
\hline Variable & Coefficient & Std. Error & t-Statistic & Prob. \\
\hline C & 0,618283 & 0,942832 & 0,655772 & 0,5171 \\
\hline $\mathbf{x 1}$ & 0,343270 & 0,116175 & 2,954764 & 0,0062 \\
\hline $\mathbf{X 2}$ & 0,135123 & 0,0866711 & 1,558307 & 0,1300 \\
\hline X3 & 0,244893 & 0,061416 & 3,987469 & 0,0004 \\
\hline X4 & 0,339324 & 0,085596 & 3,964234 & 0,0004 \\
\hline \multicolumn{2}{|c|}{ weighted statistic } & \multicolumn{3}{|c|}{ unweighted statistic } \\
\hline R-squared & 0,991704 & & lared & 0,975935 \\
\hline Adjusted R-squared & 0,987700 & Sur & red resid & 2,974246 \\
\hline Sum square resid & 2,287608 & Dur & atson stat & 3,080601 \\
\hline Durbin-Watson stat & 2,636285 & & & \\
\hline F-statistic & 247,6329 & & & \\
\hline Prob(F-statistic) & 0,000000 & & & \\
\hline
\end{tabular}

Source: Output EViews

The Fix Effect estimation model is as follows:

$$
Y=0,6182+0,3432 \times 1+0,1351 X 2+0,2448 X 3+0,3393 \times 4
$$


Based on the estimation results for the Fix Effect panel data regression model, statistically the variables $\mathrm{X} 1, \mathrm{X} 3, \mathrm{X} 4$ as independent variables have a significant effect with a probability value smaller than the critical value used, which is 0.05 or $5 \%$. Meanwhile, $\mathrm{X} 2$ as an independent variable has no significant effect with a probability value of 0.1300 and greater than 0.05 or $5 \%$.

So that the hypothesis can be concluded as follows:

1. The operational cost variable (X1) shows a coefficient value of 0.343270 with a probability value of 0.0062 . The coefficient and probability values shown explain that partially operational costs have a direct and significant effect on the contribution costs of insurance company participants from 2015 to 2018 . These results explain that an increase in the value of operating costs will increase the contribution costs of insurance company participants. Conversely, when companies can reduce the value of operating costs, the cost of participant contributions will also decrease.

2. Variable return on investment (X2) shows a coefficient value of 0.135123 with a probability value of 0.1300 . The probability value shown explains that investment returns do not partially have a significant effect on the contribution costs of insurance company participants from 2015 to 2018. These results explain that changes in the value of investments that occur in investment companies do not have an impact on changes in the value of insurance company participants' contributions.

3. The insurance claim variable (X3) shows a coefficient value of 0.244893 with a probability value of 0.0004 . The coefficient and probability values shown explain that partially insurance claims have a direct and significant effect on the contribution costs of insurance company participants from 2015 to 2018. These results explain that an increase in the value of insurance claim submissions can increase the cost of insurance participant contributions. Conversely, when the value of submitting an insurance claim is low, the cost of participant contributions also becomes low.

4. Variable tabarru' minimum risk-based funds (X4) shows a coefficient value of 0.339324 with a probability value of 0.0004 . The coefficient and probability values shown explain that partially minimum risk-based tabarru' funds have a direct and significant influence on the cost of insurance company participant contributions from 2015 to 2018. These results explain that the higher the allocation of funds for risk-based minimum tabarru' funds the insurance company will have an impact on increasing the cost of insurance participant contributions. Conversely, when companies can reduce the amount of fund allocation for risk-based minimum tabarru' funds, the cost of participant contributions will also decrease. 


\section{RESULT AND ANALYSIS}

\section{Effect of Operational Costs On Participant Contributions Costs}

The results of hypothesis testing in this study indicate that the significance value for the variable operational costs (X1) to the cost of participant contributions $(\mathrm{Y})$ is $0.0062(<0.05)$ with a coefficient value of 0.343270 . These results explain that there is a positive influence between operating costs and the contribution costs of Islamic insurance company's participants from 2015 to 2018.

The results of this study explain that an increase in the value of operational costs can increase the cost of participant contributions, but when companies can reduce the company's operating costs, the cost of participant contributions can also be reduced. The higher the costs applied in the premium component, the higher the nominal premium determined so that the obligations of the policyholder participants in paying the premiums will also be higher. However, the more efficient the operational costs of the insurance company management can allow the determination of the nominal amount of the premium will be more affordable so that the premiums deferred to the participants will be cheaper and more competitive competitively with other insurance companies (Purnomo, 2017).

The results of this study are in line with the results of research conducted by Wardhani and Septiarini (2017) which show a significance value of $0.0046(<0.05)$. The results of previous studies explained that the source of operational costs for insurance companies obtained from the cost of participant contributions. If the company cannot improve its operational costs, the company will increase the cost of participant contributions (Wardhani \& Septiarini, 2017). According to research conducted by Purnomo (2017), the higher the costs applied to participant contributions, the higher the contribution of participants charged to prospective policyholders. The higher efficiency of insurance operational management costs enables the determination of participant contributions that are cheaper and more competitive.

The results of the research conducted are also supported by the results of research by Soedibjo and Fitriati (2009), explaining that the higher the cost of participant contributions, the greater the number of funds allocated for insurance company operational costs. The operational costs themselves are all forms of costs incurred by insurance companies to be able to support the company's operational activities to create profits (Soedibjo \& Fitriati, 2009). Companies that carry out greater operational activities will require more operational costs so the company will increase the cost of participant contributions to meet those needs.

\section{Effect of Investment Results Against Participant Contribution Costs}

The results of hypothesis testing in this study indicate the significance value for the investment return variable $(\mathrm{X} 2)$ to the cost of participant contributions $(\mathrm{Y})$ amounting to 0.1300 (>0.05). These results explain that investment returns have no 
effect on the contribution costs of participants of sharia general insurance companies from 2015 to 2018. Changes in the value of investment returns from sharia general insurance companies, both decreases and increases, do not have a significant impact on changes that occur in the costs of participant contributions.

This was explained in Kontan news (n.d.) that the OJK recorded investment returns from the sharia general insurance industry sector until August 2018 was minus Rp. 542 billion. That happened because of the investment climate and unfavorable macroeconomic movements. However, the Islamic insurance industry has succeeded in increasing its assets despite depressed investment performance. Sharia insurance assets were recorded at Rp 41.6 trillion as of August 2018, up from the previous year of Rp 37.3 trillion. It shows that the allocation of investment proceeds can be allocated to increase assets and does not affect or change any value on the number of participant contributions determined by the insurance company (Kontan, n.d.).

\section{Effect of Insurance Claims on Participant Contribution Costs}

Hypothesis testing results in this study indicate that the significance value for insurance claims (X3) to the cost of participant contributions is 0,0004 $(<0.05)$ with a coefficient value of 0.244893 . These results explain that insurance claims have a positive and significant effect on the contribution costs of Islamic insurance company's participants from 2015 to 2018.

The results of this study explain that increasing the nominal claims obtained by participants can increase the cost of participant contributions. Conversely, when the nominal claims of participants have decreased, the cost of participant contributions will decrease. The results of this study support the results of research conducted by Wardhani and Septiarini which showed a significance value of $0.0000(<0.05)$. These results explain that increasing insurance claims can increase the risk for insurance companies, so the company will decide to increase the cost of participant contributions (Wardhani \& Septiarini, 2017).

Claims come from collecting collective participant funds put together in a special account (tabarru' funds) with the concept of jointly taking risks for participants who experience a disaster or loss so that they can be fully claimed by the relevant participant to the relevant insurance company (Damayanti, 2016). This insurance claim is a right for insurance participants. On the other hand, claims also become obligations for insurance companies that are bound in the participant's contract (Sula, 2004). Explained by Saniatuslima and Suprayogi (2015), one of the principles in the sharia insurance business is the sharing of risk between participants and companies in protecting participants. This principle can be applied when there is an increase in claims made by participants, so the company will increase the cost of participant contributions. This is because the company has an obligation to pay obligations to participants, and to fulfill these obligations, the greater the role of participant contributions (ta'awun) will increasingly be able to support the company. 


\section{Effect of Minimum Tabarru' Funds Based on Company Risk Against Participant Contribution Costs}

Hypothesis testing results in this study indicate that the significance value for the minimum risk-based tabarru' funds (X4) on the cost of participant contributions is $0,0004(<0.05)$ with a coefficient value of 0.339324 . These results explain that the minimum risk-based tabarru' funds of the company have a positive and significant effect on the contribution costs of sharia general insurance company participants from 2015 to 2018.

The results of this study explain that increasing the risk-based minimum tabarru' allocation in insurance companies will encourage companies to increase the cost of participant contributions. However, when the minimum risk-based tabarru' allocation of funds decreases, the amount of the company's contribution costs also decreases. These results are in line with research by Archer et al. (2009) which explains that the components in participant contributions (premiums) are a risk, savings, and investment.

Benchmarks in determining the contribution rate of participants are very dependent on the high or low risk of the participant and the amount of coverage. If the risk possessed by the participant is very high, the insurance company will project and calculate in detail the likely risks that will occur so that the loss will automatically be high too so that the cost of the contribution (premium) charged by the participant will be high because the risk and contribution of the participant are directly proportional (Triandaru \& Budisantoro, 2006). Minimum risk-based tabarru' funds in the financial statements of Islamic insurance companies consist of several components, namely credit risk, liquidity risk, market risk, insurance risk, and operational risk. This type of risk is the risk that is anticipated by the minimum riskbased tabarru' funds (Soedibjo \& Fitriati, 2009).

This is stated in the Minister of Finance Regulation No.10 / 2011 which stipulates that the allocation of tabarru' funds to Islamic insurance companies is a minimum of $30 \%$. It aims to anticipate all types of risk of losses arising as a result of deviations in asset and liability management (Financial Services Authority (OJK), 2016). The statement explained that the higher the risk of insurance companies, the company will need a larger risk-based minimum tabarru' fund allocation so that it can have an impact on increasing the contribution of insurance company participants.

\section{Effect of Operating Costs, Investment Results, Claims and Minimum Tabarru Funds' Based on Company Risk Against the Contribution Costs of Participants}

Based on the results of the analysis of the simultaneous influence of operational costs (X1), investment returns (X2), insurance claims (X3), and minimum risk-based corporate tabarru' funds (X4) have a significant and positive effect on the 
contribution costs of sharia insurance company participants $(Y)$ period from 2015 to 2018, where the known F-statistic probability values are shown at 0.00 million. The probability value shown has a value lower than the level of significance $(\alpha)$ of 0.05 , which means this research model rejects $\mathrm{H}_{0}$ and accepts $\mathrm{H}_{1}$. Thus, if the company requires costs incurred for the company's operations and pay claims to participants who experience losses and meet the minimum risk-based tabarru' funds for the company, it is expected that Islamic general insurance companies can determine the amount of contribution of participants who can afford it all.

This is in line with previous research which states that the appropriate contribution of participants must be determined in order to be able to pay claims, cover operational costs, and get benefits (Indriani et al., 2019). This is also reinforced by research by Soedibjo and Fitriati (2009) which states that achieving an optimal portfolio of participant contributions can break even where it depends on the type of product being marketed, operational costs, investment returns, and the level of risk of potential participants

\section{CONCLUSION}

Operational costs partially have a significant positive effect on participant contributions, with a significant value of 0.0062 , on participant contributions. If the operational cost variable increases by one unit while the other independent variables are considered constant, the contribution of participants will increase by 0.343270 units. Partial investment results did not significantly influence the contribution of participants with a significant value of 0.1300 . This shows that the investment return variable has increased by one unit, while other independent variables are considered constant, the contribution of participants will increase by 0.135123 units.

Claims partially significant positive effect on the contribution of participants with a significant value of 0,0004 , so that the claim variable has increased by one unit, while other independent variables are considered constant, then the contribution of participants will increase by 0.244893 units.

Minimum risk-based tabarru' funds partially have a significant positive effect on the contribution of participants with a significant value of 0,0004 . If the risk-based minimum tabarru' variable increases by one unit, while other independent variables are considered constant, the contribution of participants will increase by 0.339324 units. Operating costs, investment returns, claims, and minimum risk-based tabarru' funds simultaneously have a significant positive effect on the participant contribution of 0.0000 . If the variable operational costs, investment returns, claims, and minimum risk-based tabarru' funds have increased by one unit, while other independent variables are considered constant, the participant contribution will increase by 247.6329 units. 


\section{REFERENCES}

Al Arif, \& Muhammad Nur R. (2012). Lembaga Keuangan Syariah. Pustaka Setia.

Anwar, K. (2004). Asuransi Syariah, Halal \& Maslahat. Tiga Serangkai.

Archer, Rifaat, \& Volker. (2009). Takaful Islamic Insurance Concept and Regulatory Issue. John Willey and Sons.

Astria, D. (2009). Analisis Faktor-Faktor yang Mempengaruhi Laba PT Asuransi Takaful Keluarga. Institut Pertanian Bogor.

Billah, M. (2001). Principles \& practices of takaful and insurance compared. In International Islamic University, Malaysia-2001. IIUM Press. https://scholar.google.com/scholar?hl=en\&q=takaful\&btnG=\&as_sdt=1\%2C5\&a s_sdtp=\#18

Damayanti, F. E. (2016). Pengaruh Kontribusi Peserta, Klaim, Dan Hasil Investasi Terhadap Surplus Underwriting Asuransi Umum Syariah Di Indonesia [Universitas Airlangga]. http://repository.unair.ac.id/33108/

Dewi, K. V., \& Witjaksono, A. (2015). Evaluasi Pengakuan Pendapatan dan Beban Atas Dana Tabbaru' dan Dana perusahaan pada Asuransi PT AJB BumiPutera. BINUS.

Djojosoedarsono, S. (2003). Prinsip-prinsip Manajemen Risiko Asuransi. Salemba Empat.

Duzuki, A. . (2015). International Shari'ah Research Academy for Islamic Finance (ISRA) Sistem Keuangan Islam. Rajawali Pers.

Ernst \& Young Global Limited. (2014). Global Takaful Insights 2014 Market updates. EY Global Limited.

Ghozali, I. (2018). Aplikasi Analisis Multivariate dengan Program IBM SPSS. Yogyakarta: Universitas Diponegoro. Badan Penerbit Universitas Diponegoro.

Huda, \& Nasution. (2009). Current Issue Lembaga Keuangan Syariah. Kencana.

Hwang, T., \& Greenford, B. (2005). A Cross-Section Analysis of the Determinants of Life Insurance Consumption in Mainland China, Hong Kong, and Taiwan. Risk Management and Insurance Review, 8(1), 103-125. https://doi.org/10.1111/j.1540-6296.2005.00051.x

Indriani, R., Canggih, C., \& Rusmita, S. A. (2019). Efficiency Determinants of Islamic Insurance in Indonesia. The 2nd International Conference on Islamic Economics, Business, and Philanthropy (ICIEBP) Theme: "Sustainability and Socio Economic Growth, Publisher KnE Social Sciences, 175-182.

Kontan. (n.d.). Hasil Investasi Asuransi Syariah Minus Rp 542 Milliar. https://keuangan.kontan.co.id/news/hasil-investasi-asuransi-syariah-minus-rp542-miliar

Kuncoro. (2013). Metode Riset Untuk Bisnis dan Managemen. Erlangga.

Kuncoro, M. (2007). Metode kuantitatif : teori dan aplikasi untuk bisnis dan ekonomi. In System. UPP STIM YKPN.

Kurnia, S. (2017). Perkembangan Asuransi Kesehatan Swasta di Indonesia 2012 - 2016. Jurnal Ekonomi Kesehatan Indonesia, 2(2). https://doi.org/10.7454/eki.v2i2.2142

Middle East Global Advisors. (2016). World Takaful Report 2016. 11th Annual World Takaful

Conference.

http://www.takafulprimer.com/main/downloads/ms_5860.pdf

Nasution, N. H. \& M. E. (2008). Investasi Pada Pasar Modal Syariah. Kencana.

Otoritas Jasa Keuangan. (2016). Peraturan Otoritas Jasa Keuangan (POJK) Nomor 71 / 
POJK.05/2016 tentang Kesehatan Keuangan Perusahaan Asuransi dan Perusahaan Reasuransi.

https://www.ojk.go.id/id/kanal/iknb/regulasi/asuransi/peraturan-

ojk/Pages/POJK-tentang-Kesehatan-Keuangan-Perusahaan-Asuransi-dan-

Perusahaan-Reasuransi.aspx

Prodjodikoro, W. (1958). Hukum Asuransi Indonesia. Pembimbing.

Purnomo, A. (2017). Analisis Pembayaran Premi Dalam Asuransi Syariah. Al-Uqud: Journal of Islamic Economics, 1(1), 27. https://doi.org/10.26740/jie.v1n1.p27-40 Puspitasari, N. (2015). Manajemen Asuransi Syariah. UII Press.

Saniatuslima, H., \& Suprayogi, N. (2015). Manajemen Resiko Dana Tabarru' Pt Asuransi Jiwa Syariah Al Amin. Jesit, 2(12), 1002-1018.

Sianturi, I. R. (2014). Pengaruh Beban Klaim, Current Rasio, Pertumbuhan Premi Terhadap Return On Invesment. Universitas Maritim Raja Ali Haji.

Soedibjo, S., \& Fitriati, R. (2009). untuk Mencapai Titik Impas dengan Pendekatan Model Profit Testing. Jurnal Ilmu Administrasi Dan Organisasi, 16, 59-67.

Soemitra, A. (2009). Bank dan Lembaga Keuangan Syari'ah. Perdana Media Group.

Sula, M. S. (2004). Asuransi Syariah (Life and General) : Konsep dan Sistem Oprasional. Gema Insani.

Triandaru, S., \& Budisantoro, T. (2006). Bank dan Lembaga Keuangan Lain. Salemba Empat.

Wardhani, R. K. M., \& Septiarini, D. F. (2017). Faktor-Faktor Yang Mempengaruhi Kontribusi Peserta Pada Perusahaan Asuransi Jiwa Syariah Di Indonesia. Jurnal Ekonomi Syariah Teori Dan Terapan, 4(10), 802-816. https://doi.org/http://dx.doi.org/10.20473/vol4iss201710pp802

Wirdyaningsih. (2005). Bank dan Asuransi Islam Di Indonesia. Kencana. 